\title{
INFLUENCE OF GRADED LEVELS OF INSTANT NOODLE WASTE IN THE DIETS ON THE PERFORMANCE, CARCASS TRAITS AND HAEMATOLOGY OF BROILER CHICKENS
}

\author{
Animashahun R. A ${ }^{a}$, Omoikhoje S. Ob, Alabi, O.O a, Shoyombo, A.Ja and Olawoye S.O.b. \\ a Department of Animal Science, Landmark University, P.M.B. 1001, Omu Aran, Kwara State, \\ Nigeria.
}

b Department of Animal Science, Ambrose Alli University, P.M.B. 14, Ekpoma, Edo State, Nigeria.

*corresponding author: animashaun.rasaq@Imu.edu.ng and kunleannies@yahoo.com

\begin{abstract}
An eight week feeding trial was conducted to assess the replacement value of instant noodle waste meal (INW) on the performance characteristic, carcass and haematological parameters of broiler chickens. Ninety, one-day old Anak 2000 chicks were randomly allocated to three treatment groups namely, diet $1(0 \%$ INW), diet 2 (50\% INW) and diet $3(100 \%$ INW) in a completely randomized design (CRD). Each treatment group had three replicates of ten chicks each. The inclusion of instant noodle in the diet did not have significant $(P>0.05)$ effect on the performance of the broiler chickens at both starter and finisher phases. The inclusion of instant noodle waste had no significant $(P>0.05)$ effect on the carcass traits and organ weights in broiler chickens. No significant ( $P>0.05$ ) effect was observed for the packed cell volume, hematocrit, haemoglobin, leucocytes, and mean corpuscular haemoglobin concentration among the treatments. However, mean corpuscular volume and mean corpuscular haemoglobin were significantly $(P<0.05)$ influenced by the instant noodles inclusion, in the diets. Based on the present results INW could replace maize fraction of the diet partially or wholly without any adverse effect on performance, carcass and health status of broiler chickens.
\end{abstract}

Keywords: Broiler chickens, Instant noodle waste, Performance Carcass traits, Haematological indices 


\section{INTRODUCTION}

The intake of animal protein in Nigeria was estimated to be $4.82 \mathrm{~g} / \mathrm{head} / \mathrm{day}$ (Manary, 2013) compared to the recommended minimum intake of $35 \mathrm{~g} / \mathrm{head} /$ day require for proper growth, reproduction, lactation, health and survival (FAO, 2009). The observed low level of animal protein intake has its root cause in the high cost of feeding farm animals for optimum growth and production (Durumaet al., 2006) as feed constitute up to 76,74 and $73 \%$ of the cost of production for the small, medium and large scale producers (Olorunsanya, 2004). Hence, the key to sustainable animal production is availability of cheap feed as feed is the major determinant of livestock production in terms of quantity, and turnover rate (Olorunsanya, 2004).

Poultry production especially the production of broiler chickens offers the greatest scope for increasing the quality and quantity of protein intake in Nigeria because of the short generation interval and prolificacy (Ezema and Eze, 2009). The chief source of energy in the diets for monogastric animal in Nigeria is maize (Zea mays), but it is also required by man and processing industries. There has been an increasing demand for maize in Nigeria and this has resulted in the escalation in the price, and reduction in the amount used in diet for livestock; this therefore calls for concerted effort in search of alternative cheap sources of feed ingredients that have little or no competition from human consumption (Ukachukwu, 2005).

Agro industrial waste by-products in recent years have become popular feed components in poultry diets in Nigeria (Eustace, 2005 and Adeyina et al., 2008). Examples of such products include wastes from the kitchen, from the canning industries, potato pomace waste, citrus fruit wastes, bakery waste, kolanut testa meal, cocoa kernel meal, pigeon pea meal, bambara groundnut meal, cashew nut waste meal, etc. Adeyeye (2005) observed that the use of decorticated cashew nut meal in place of soya bean meal in broilers feed enhanced the carcass traits of broiler chickens. Leaves and tender stem of cassava have been incorporated into broilers feed with encouraging result (Aderemi,et al., 2004). Oyedeji et al (2015) reported no detrimental effect of blood rumen content mixture (BRCM) meal supplemented with yeast on the performance and gut microbial populations of broiler chickens. Also Lamidiet al. (2008) observed no adverse effect on the performance of chicken when $10 \%$ pineapple crush meal was used to replace maize. Omoikhoje et al. (2010) reported enhanced growth, nutrient digestibility and blood profile when corn flakes waste was incorporated into broilers diet to replace $75 \%$ maize. Aderolu et al. (2011) also observed a better growth performance in African catfish as a result of inclusion of instant noodle waste to replace $75 \%$ maize.

Since the introduction of instant noodle meal into Nigeria culinary, it has become popular, well accepted and found in the kitchen of almost all Nigerian homes (Business News, 2006). This has resulted in the great explosion of the industry and corresponding level of waste from this 
sector. Instant noodle has several advantages over other non-conventional feed ingredients: since instant noodle is meant for human consumption, it is hygienically packaged and this removes the fear of contamination. Instant noodle waste has no known anti-nutritional factors, and it also possesses higher metabolizable energy than maize (Laila et al., 2010; Eniolorunda, et al., 2008). The proximate composition of instant noodle waste (INW) has been reported to be comparable to that of maize (Laila et al., 2010) as shown in Table 1. Instant noodle waste is a suitable energy source, it is not in direct competition with humans as food, need no further processing before its inclusion in the diet, has a stable and affordable price when compared with maize. With the recent increase in consumption and acceptability of instant noodles as fast food in the country and the complementary increase in producers and production, a lot is being discarded as waste. This study was therefore designed to determine the performance characteristics and haematological indices of broiler chickens fed varying levels of instant noodle waste meal.

\section{MATERIALS AND METHODS}

Location of the study: The experiment was carried out at the Poultry Unit of Teaching and Research Farm of Ambrose Alli University, Ekpoma for a period of eight (8) weeks.

Sources of ingredients: The instant noodle waste for the feeding trial was purchased from Dangote Flour Mills, llupeju-Lagos, Nigeria. Other feed ingredients were sourced from Ekpoma, Edo State of Nigeria.

Experimental chicks design and management: $A$ total of ninety day-old broiler chicks were used for the study. The chicks were randomly assigned to three dietary treatments namely diet $1(0 \%$ INW), diet $2(50 \%$ INW) and diet $3(100 \%$ INW). Each treatment group contained three replicates of ten chicks each. All the chicks were brooded for four weeks in a deep litter system. The house, feeders and drinkers were properly washed and disinfected. The chicks were fed a commercial broiler starter diet for one week acclimatization period. All through the feeding trial, the birds had free access to the experimental feeds and clean water ad libitum. Routine medication, vaccination and other management practices were carried out.

Experimental diets: A total of three treatment diets of both starter and finished phases were formulated as reflected in Table 2. Diet 1 was formulated to contain $0 \%$ instant noodle waste meal (INW), while diets 2 and 3 were formulated by replacing the level of maize in Diet 1 with 50 and $100 \%$ levels of INW respectively. All the diets were formulated to be isonitrogenous (21 and $19 \%$ crude protein for the starter and finisher phase respectively) and isocaloric (2800 and 3000.ME Kcal/kg for the starter and finisher phase respectively). 


\section{Performance characteristic study:}

Prior to the beginning of the experiments, the birds were weighed to obtain their initial body weight and subsequently on weekly basis. The performance parameters measured were feed intake, body weight gain and feed conversion ratio.

Feed intake: A known quantity of feed was given to the chicks on daily basis while the leftover of feed was weighed to determine daily feed intake and consequently weekly feed intake. All birds were fed ad libitum each day to ensure adequate access to feed.

$$
\text { Feed supplied - Leftover of feed }
$$

Feed intake per bird $=$

Number of birds

Weight gain: The live weight gains were recorded on weekly basis. The initial live weight was deducted from the final live weight and divided by the number of birds per treatment compartment. Birds were usually weighed before feeding in the morning.

Final live weight - Initial live weight

Weight gain $=$

\section{Number of birds/treatment/replicate}

Feed conversion ratio: Feed conversion ratio of each group of birds was determined by calculating the ratio of feed intake to weight gain and thus calculated as:

Feed intake

Feed conversion ratio $(\mathrm{FCR})=$

\section{Carcass quality study}

Weight gain

At the end of eight weeks feeding trial, the birds were fasted overnight and two chickens were selected from each replicate and weighed. Thereafter, the birds were slaughtered, bled, 
plucked and eviscerated. The weights of the plucked and eviscerated chickens were taken, while the eviscerated weight relative to the live weight was used to estimate the dressing percentage of the birds. Later, the dressed chicken was cut into parts such as: the thigh, drumstick, breast, wing, shank, head, neck and back and their weights taken relative to the eviscerated weights.

Blood sample collection and preparation: Three birds each were randomly selected from each replicate on weight equalization basis and blood samples were collected terminally from each of them through wing vein using syringe and needle. About $5 \mathrm{ml}$ of blood sample were collected from each bird into a labeled ethylene diamine tetra acetic acid (EDTA) specimen bottles for haematological indices determination.

Determination of haematological indices: Packed cell volume (PCV), red blood cell (RBC), white blood cell (WBC), haemoglobin were determined using improved Neubaurhaemacytometer after dilution and cyanomethaemoglobin methods respectively as described by Dacie and Lewis (1991), while the standard ratios of the mean corpuscular volume (MCV), mean corpuscular haemoglobin $(\mathrm{MCH})$ and mean corpuscular haemoglobin concentration were calculated according to Jain (1986).

\section{Statistical analysis}

The experimental design was a Completely Randomized Design (CRD) and data obtained were subjected to Analysis of Variance (ANOVA). Significant differences among treatment means were determined using Duncan Multiple Range Test as contained in SAS (2011) package.

\section{RESULTS AND DISCUSSION}

The performance characteristics of broilers fed diet differing in INW are presented in Table 3. At the starter phase, no significant difference $(P>0.05)$ was observed in all the growth parameters tested for. However, highest daily feed intake was observed in diet 3, while least value was obtained in diet 2 . The values obtained for average daily weigh gain showed that birds fed with diet 2 had the best weight gain compared to diets 1 and 3 . The result also showed that there was better utilization of diet 2 as indicated by the calculated feed conversion ratio. At the finisher's phase, there was no significant difference in the values obtained for average daily feed intake and average live weight, there were significant differences $(P<0.05)$ in the values observed for average daily weight gain and the feed conversion ratio at this phase. However, the values obtained for diets 1 and 3 were significantly similar; higher feed intake observed in diet 3 is in agreement with the findings of Olayemi (2007) and Eniolorunda, et al. (2008) who reported an increase in feed intake as the INW increases from $0-100 \%$. 
Data on the carcass characteristics of broiler chickens are shown in Table 4. It was observed that the inclusion of instant noodles did not have significant $(P>0.05)$ effect on the carcass characteristics of broiler chickens. The values obtained for the average live weight, defeathered weight, eviscerated weight, dressing percentage, the drumsticks, breast, thighs and wings numerically higher at diet 2 and reduced to the lowest at diet 3 . Since the average live weight, defeathered and eviscerated weights were not significantly $(P>0.05)$ increased as the level of inclusion of INW increased in the diets, it therefore implies that the quality of the test ingredient in the diets is capable of effective tissue synthesis in finisher broiler chickens under the same environmental condition. The dressing percentage of broiler chickens (ranged between 80.86 and 85.92) were significantly similar amongst the treatment groups and the values obtained are consistent with the range of values reported by Lamidiet al (2008), Fapohunda et al., (2008), and Adejinmi et al., (2011) for broiler chickens.

The results on haematological indices (Table 5) revealed that packed cell volume (PCV), red blood cells $(\mathrm{RBC})$, haemoglobin $(\mathrm{Hb})$, white blood cells $(\mathrm{WBC})$ and mean corpuscular haemoglobin concentration $(\mathrm{MCHC})$ were not significantly $(\mathrm{P}>0.05)$ different from one another, while mean corpuscular volume (MCV), mean corpuscular haemoglobin ( $\mathrm{MCH}$ ) were significantly $(P<0.05)$ affected by the test diets.. This result was in agreement with Akinola and Etuk (2015) and Mitruka and Rawnsley (1997). The haemoglobin values obtained in this study indicate that the oxygen carrying capacity of the bird's blood by haemoglobin was relatively the same. It has also been established that an animal with decrease in the level of haemoglobin in the blood is indicative of poor nutrition including dietary deficiency of iron, amino acid and vitamins (Afolabi and Oladimeji, 2003; Mitruka, and Rawnsley 1997; Aletor, and Egberongbe, 1992). The WBC plays a major role in defending the body against disease-producing bacteria, viruses and fungi; a deficiency in WBC may result in an increased susceptibility to infections. A decrease in white blood counts is a reflection of the decline in the production of WBC for defensive action against infection.

The results obtained in the study buttress the fact that INW had no detrimental effect on health status of the birds and could be used as alternative feed resource in the diet of broiler chickens. Mean corpuscular volume was significantly $(P<0.05)$ highest in broilers maintained on diet 3 , followed by those that ate diet 1 and least in those maintained on diet 2. Mean corpuscular haemoglobin was significantly $(\mathrm{P}<0.05)$ higher in birds maintained on the control diet (diet 1), followed by those that ate 100\% IWM (diet 3) and least in those maintained on the $50 \%$ INW (diet 2) based diet. Blood is very vital to life and any abnormal variation in the haematology of the cell impairs the primary physiological functions of the animal's body (Akinmutimi, 2006; Bamgbose et al; 2004; Omoikhoje et al; 2010). Esonu et al (2001) reported that haematological constituents are reflection of animal's responsiveness to both internal and external 
environments which include feeds and feeding. The haematological parameters obtained suggest that all the broiler chicken irrespective of the test diet inclusion level had normocytic and normochromic red blood cells. This implies that the inclusion of INW up to $100 \%$ did not affect the utilization of iron by the birds. The similarities in the values of PCV, RBC, $\mathrm{Hb}$, and $\mathrm{MCHC}$ among the birds irrespective of the test diets could be an indication that the test diet has no adverse effect on the erytopoiesis activities of the chickens fed the test diet; since haematocrit and haemoglobin are known to be positively correlated with protein quality and protein level in the feed; the increase in the levels of MCV and $\mathrm{MCH}$ as the level of INW increased indicates the high quality of the diets. All the haematological values including the WBC fell within the normal range for healthy broiler chickens (Maxwell et al, 1990; CCAC, 1993; Ikhimioya, et al., 2000; Banerjee, 2009; Nkwocha, et al., 2014)

\section{CONCLUSION}

Instant noodles waste meal (INW) could replace maize in the diet of broiler chickens. The haematological indices and carcass yield of broiler chickens in this study revealed the adequacy of the INW inclusion up to $100 \%$ level in broiler diets; however, better result was achieved in birds fed diet containing 50\% INW.

Table 1: Proximate composition of instant noodle waste and maize $(\% \mathrm{dm})$.

\begin{tabular}{lcc}
\hline Composition & INW & Maize \\
\hline Dry matter (\%) & 89.00 & 91.80 \\
Crude protein (\%) & 8.57 & 8.90 \\
Crude fibre (\%) & 2.80 & 2.70 \\
Ether extract (\%) & 17.14 & 4.00 \\
Ash (\%) & 0.90 & 1.30 \\
NFE & 59.59 & 74.90 \\
ME (Kcal/Kg) & 3799 & 3315 \\
\hline
\end{tabular}

Source: Laila (2010) 
Table 2: Composition of experimental starter and finisher diets

\begin{tabular}{|c|c|c|c|c|c|c|}
\hline \multirow[b]{2}{*}{ Ingredients } & \multicolumn{3}{|c|}{ Starter phase } & \multicolumn{3}{|c|}{ finisher phase } \\
\hline & $\mathrm{T} 1$ & $\mathrm{~T} 2$ & T3 & $\mathrm{T} 1$ & $\mathrm{~T} 2$ & T3 \\
\hline Maize & 42.90 & 21.45 & 0.00 & 53.10 & 26.55 & 0.00 \\
\hline Instant noodle waste & 0.00 & 21.45 & 42.90 & 0.00 & 26.55 & 53.10 \\
\hline Soya bean meal & 21.75 & 21.75 & 21.75 & 27.75 & 27.75 & 27.75 \\
\hline Groundnut cake & 15.00 & 15.00 & $15 . .00$ & 15.00 & 15.00 & 15.00 \\
\hline Fish meal & 1.00 & 1.00 & $1 . .00$ & 1.05 & 1.05 & 1.05 \\
\hline Wheat offal & 16.24 & 16.24 & 16.24 & 0.00 & 0.00 & 0.00 \\
\hline Oyster shell & 2.36 & 2.36 & 2.36 & 2.38 & 2.38 & 2.38 \\
\hline Premix & 0.25 & 0.25 & 0.25 & 0.25 & 0.25 & 0.25 \\
\hline DL Methionine & 0.10 & 0.10 & 0.10 & 0.10 & 0.10 & 0.10 \\
\hline DL Lysine & 0.10 & 0.10 & 0.10 & 0.10 & 0.10 & 0.10 \\
\hline Salt & 0.30 & 0.30 & 0.30 & 0.30 & 0.30 & 0.30 \\
\hline Total & 100 & 100 & 100 & 100 & 100 & 100 \\
\hline Crude Protein \% & 21.20 & 20.70 & 20.85 & 18.82 & 18.74 & 18.66 \\
\hline Metabolizable energy (Kcal/Kg) & 2800 & 2813 & 2825 & 3000 & 3015 & 3031 \\
\hline
\end{tabular}

Table 3: Performance characteristic of broiler chicken fed the experimental diets

\begin{tabular}{|c|c|c|c|c|c|c|c|c|}
\hline & \multicolumn{4}{|c|}{ Starter phase } & \multicolumn{4}{|c|}{ Finisher phase } \\
\hline Ingredients & $\mathrm{T1}$ & $\mathrm{T} 2$ & T3 & SEM & $\mathrm{T1}$ & T2 & T3 & SEM \\
\hline Average live weight (g/bird) & 533.33 & 536.67 & 473.33 & 26.03 & 2130 & 2300 & 2100 & 0.09 \\
\hline $\begin{array}{l}\text { Average daily feed intake } \\
\text { (g/bird) }\end{array}$ & 63.01 & 62.70 & 65.87 & 2.78 & 136.06 & 135.39 & 141.73 & 0.56 \\
\hline
\end{tabular}




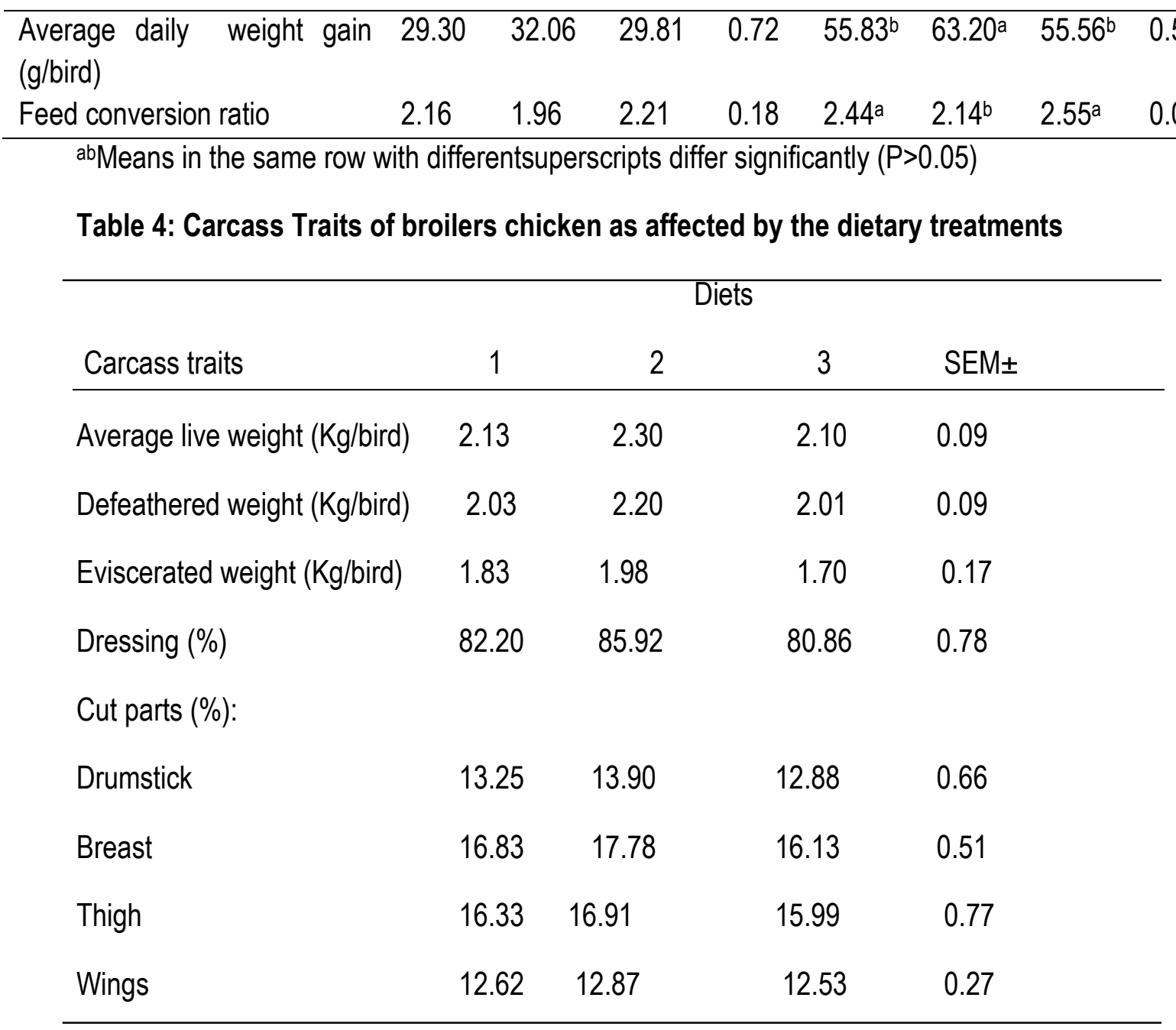

Table 5: Haematological indices of broiler chickens as affected the dietary treatments.

Diets

\begin{tabular}{lcccc} 
Indices & 1 & 2 & 3 & SEM \pm \\
\hline $\mathrm{PCV}(\%)$ & 31.63 & 32.80 & 29.03 & 0.96 \\
$\mathrm{RBC}(\times 106 / \mu \mathrm{l})$ & 2.47 & 2.61 & 2.20 & 0.08 \\
$\mathrm{Hb}(\mathrm{g} / \mathrm{dl})$ & 10.30 & 10.53 & 9.40 & 0.38 \\
$\mathrm{WBC}\left(\times 10^{3} / \mu \mathrm{l}\right)$ & 260.13 & 271.70 & 257.10 & 2.43
\end{tabular}




\begin{tabular}{lcccc}
$\mathrm{MCV}(\mathrm{fl})$ & $128.80^{\mathrm{b}}$ & $125.83^{\mathrm{c}}$ & $132.50^{\mathrm{a}}$ & 0.21 \\
$\mathrm{MCH}(\mathrm{pg})$ & $42.77^{\mathrm{a}}$ & $40.23^{\mathrm{c}}$ & $41.73^{\mathrm{b}}$ & 0.25 \\
$\mathrm{MCHC}(\mathrm{g} / \mathrm{dl})$ & 32.50 & 32.07 & 32.37 & 025 \\
\hline
\end{tabular}

abc Means in the same row with different superscripts differ significantly $(P<0.05)$.

\section{REFERENCES}

Adeyina, A. O., Annongu, A. A. and Awe, O.(2008). Effects of cocoa bean shell on the performance, blood indices and organ characteristics of cockerels. Agrosearch 10 (1). Pp: 11 - 19

Afolabi, O. and Oladimeji, H. (2003). Haematological studies of some avian species. International Journal of Poultry Science. 30 (2): 24.

Adejinmi, O. O., Okpeze, C.N.Obi, O.O.,Omole, A.J., Kehinde, A.S., Awe, O.A. (2011).The use of chicken egg shell as an alternative source of calcium in the diet of cockerel chicken. Journal of Agriculture and Social Sciences: pp. 34-38

Aderemi, F.A, Ladokun,O.A. and Tewe, 0.0 (2004). Study on haematology and serum biochemistry of layers fed biodegraded cassava root sievate. Bowen Journal of Agriculture.1 (1) Pp: 78-83

Aderolu, A. Z., Aarode, O.O. and Adigun, A (2011). Replacement of maize with graded levels of noodle waste in commercial diet of African catfish. Nigerian Journal of Fisheries 8 (2)

Adeyeye, S.A. (2005). National significance of broiler chickens, (Anacardium occidentale) nut meal in broiler chicken, M. Agric Tech Thesis, Department of Animal Production and Health, Federal University of Technology, Akure Nigeria, Pp: 1-117.

Akinmutimi, A.H. (2006). Nutritive value of raw and processed jack fruit seeds (Articarpus heterophilus). Chemical Analysis . 4: 266-271

Akinola, L.A.F and Etuk, M.O (2015). Haematological and Serum Biochemical Responses of Broilers Fed Varying Levels of Indomie Waste-Based Diet. Journal of Agriculture and Veterinary Science 8(3), Pp 66-70. e-ISSN: 2319-2380 DOI: 10.9790/2380-08316670

Aletor, VA. and Egberongbe, O.(1992).Feeding differently processed soybean and assessment of haematological responses in chicken. Die Nahrung 36: 367 - 370. 
Banerjee G.C.(2009) A textbook of Animal Husbandry 8th Ed. (Oxford and IBH Publishing Co. PVT. Ltd., New Delhi, India,, 118- 139

Business news (2006). "The Noodles War | The NEWS - Nigeria's authoritative weekly newsmagazine"Thenewsng.com.2008-07-21. http://thenewsng.com/article/857?version=print. Retrieved 2009-05-29.

CCAC-Canadian Council of Animal Care (1993). Breeding physiological and nutritional parameters by species. Experimental Animals $2^{\text {nd }}$ edition http://www.yonsei.ac.kr) pp 1-3

Dacie J.V and Lewis, S. (1991).Practical haematology $8^{\text {th }}$ edition Longman group Ltd. Pp: 2268

Ezema, C. and Eze, D.C. (2009). Performance and Economic Benefit of Broilers Fed Palm Kernel Cake-Based Diet Supplemented with Probiotic. International Journal of Poultry Science 8 (10): 1003-1005, 2009 ISSN 1682-8356 @ Asian Network for Scientific Information

Duruma C. A., Udibie, A.B.I. and Etuk, E.B. (2006).Performance and organ characteristic of broiler chickens fed graded level of Anthonatamacrophyla seed meal as replacement for Arachis hypogeal meal. Proceeding of 11' Annual Conference of ASAN Pp: 211 -215

Eniolorunda, O.O., Taiwo, B. B. A., Oyewumi, O.O. and Adeyemi, O.A. (2008). Performance of laying hens fed graded levels of indomie waste as replacement for maize in humid Tropical environment. Research Journal of Animal Sciences 2 (5): 135-138.

Esonu, B. O., Emenalom, O.O., Udibibie, A.B.I., Herbert, U. Ekpor, C.F., Okoli, I.C and Iheukwumere, F.C. (2001). Performance and blood chemistry of weaner pigs fed raw Mucuna (Velvet bean) meal.Trop. Anim. Prod. Invest. 4:49-54

Eustace (2005). Effect of Enzyme supplementation on palm kernel meal and brewers dried grain on the performance of broilers. International Journal of Poultry Science 4 (2): 76-80.

F.A.O (2009): Food outlook. Food and Agricultural Organization Corporate Document Repository. http://www.fao.org/docrep

Fapohunda, J.B., Adejinmi, O.O.,Okpeze, C.N.,Owosibo, O.A. and Bamigbose, A.M. (2008) Effect of replacing maize with biscuit waste in the diet of cockerels. Proceeding of the $13^{\text {th }}$ Annual conference of the Animal Science Pp: 318-321 
Ikhimioya, A. Arijeniwa, I. Oleku, T. and Ahmed, A,(2000). Preliminary investigation on the haematology of the Nigerian indigenous chicken. Proceeding of $5^{\text {th }}$ Annual Conference of Animal Science Association of Nigeria, 10- 12

Jain N.C (1986): SchalmVeteniaryHaemotology. $4^{\text {th }}$ edition philadephia, Lea and Febinger

Laila, A,O., Bamgbose, M. D., Eruvbentine M., Bemji, A.O. and Osundare,T.O. (2010): Effects of Instant noodles waste based diets as a replacement for maize on haematologicalparameters of broiler chickens. Proceeding of $15^{\text {th }}$ Annual Conference of Animal Science Association of Nigeria.(ASAN). Pp 5-7.

Lamidi, A.W., Famino, D. Eruvbetine, M and Biobaku, W.O. (2008). Effects levels of graded pineapple (Ananascomosus L. Meer) Crush waste on the performance, carcass yield and blood parameters of broiler chicken .Nig. J. Anim. Prod. 35(2): 168-170

Manary M. (2013). Inadequate dietary protein intake. Food and Nutrition Bulletin, Volume 34 No. 2 Pg. 248

Maxwell, M.H Robertson,G.W. Spence, S and McCorquodute, C.C.(1990).Comparisom of haemotological value of restricted and ad Libitum feeding in domestic fowls.Brit.poult.sci.31(3): 407-413.

Mitruka, H.M. and Rawnsley, S.K.(1997). Clinical, biochemical and haematology reference in normal experimental animal. Mason, NY. Pp. $287-380$.

Nkwocha G.A., Agbabiaka L.A., Anukam K.U. and Beketin T.O. (2014) Growth responses carcass and blood characteristics of finisher broilers fed sorghum offal meal as dietary supplement. International Journal of Agriscience. 4(7), 392-398

Olayemi T.D, Farin, G.O. and Ojebiyi, O.O. (2007).Replacement Value of biscuit waste on the performance and egg quality parameters of laying hens.Proc.32nd Ann. Conf. Anim. Sci. Ass. of Nig. (ASAN). Pp: 313-230.

Olorunsanya, A. E. O. (2004). Egg farming business in Kwara State, how profitable? Agrosearch 6 (1). Pp: 9-14

Omoikhoje, and J.A.Imasuen, 2004. Response of broilers to dietary levels of processed pigeon pea meal. Proc. Of $9^{\text {th }}$ Ann. Conf. Anim. Sci. Ass. Of Nig. (ASAN).pp 23-25. 
Omoikhoje S.O; D.OObasoyo; B.A Osifo and K.M.Iwaloye, (2010). Blood constituents of broilers chickens as affected by cornflakes waste based diets. J. of Res.And policies. 5(1), 54-58.

Oyedejl, J.O., Ajayi, H.I., Epoudo, I., Edem, I.I. and Sokondi, R.S (2015). The effects of blood rumen content mixture (BRCM) meal supplemented with yeast on the performance and gut microbial populations of broiler chickens. Agrosearch 15 (2). Pp: 93 - 105

SAS.(2011). Statistical Analysis Systems, Version 9.3, SAS, Institute Inc. Carry N.C. USA.

Ukachukwu, S. N. (2005). Studies on the nutritive value of composite cassava pellets for poultry: chemical composition and Metabolizable energy. Livestock Research for Development 17 (11) 